\title{
Germline and de novo mutations in the HRPT2 tumour suppressor gene in familial isolated hyperparathyroidism (FIHP)
}

\author{
A Villablanca, A Calender, L Forsberg, A Höög, J-D Cheng, D Petillo, C Bauters, K Kahnoski, \\ T Ebeling, P Salmela, A-L Richardson, L Delbridge, A Meyrier, C Proye, J D Carpten, B T Teh, \\ B G Robinson, C Larsson
}

J Med Genet 2004;41:e32 (http://www.jmedgenet.com/cgi/content/full/41/3/e32). doi: 10.1136/jmg.2003.012369

$\mathrm{F}$ amilial forms of primary hyperparathyroidism (PHPT) constitute a broad group of disorders in which PHPT is either a main or an associated feature. With the advances in disease gene identification, some of the genetic abnormalities underlying familial PHPT have been clarified. ${ }^{12}$ In hyperparathyroidism-jaw tumour syndrome (HPT-JT; OMIM \#145001) the affected family members frequently develop PHPT, ossifying jaw fibromas, and cystic and neoplastic renal lesions. ${ }^{3-6}$ A typical feature of HPT-JT is adenomas and carcinomas of the parathyroid glands, which often have cystic features. ${ }^{1}$ This is in contrast to the other forms of familial PHPT in which the parathyroid tumours are generally benign.

The disease locus was first mapped to chromosomal region 1q25-q32 by linkage in affected families ${ }^{3-7}$ and recently the causal HRPT2 gene was isolated through a positional cloning approach. ${ }^{3}$ The HRPT2 gene consists of 17 exons encoding an evolutionarily well conserved, 531 amino acid protein named parafibromin. The inactivating mutations demonstrated in the germline of HPT-JT kindreds and as somatic events in some sporadic parathyroid adenomas ${ }^{3}$ are in agreement with the observations of somatic loss of the wild type alleles, suggesting that parafibromin has a tumour suppressor function. ${ }^{36}$

The importance of the multiple endocrine neoplasia type 1 gene $(M E N 1)$ in familial PHPT has been well established. $M E N I$ is a tumour suppressor gene located in $11 \mathrm{q13},{ }^{8-10}$ and its encoded protein menin has been shown to interact with several proteins involved in transcriptional regulation. ${ }^{11}{ }^{12}$ The MEN1 syndrome (OMIM \#131100) is clinically characterised by the frequent development of tumours in the parathyroids, the endocrine pancreas and duodenum, and the anterior pituitary gland. MENl, which is the most common form of hereditary PHPT, is caused by germline mutations of MEN1, both in the form of inherited mutations in families and de novo mutations in isolated MENl cases..$^{13}{ }^{14}$ Less frequently, familial PHPT is seen in familial hypercalcaemic hypercalciuria or the homozygous form of familial hypercalcaemic hypocalciuria (FHH), which are both associated with germline mutations in the calcium receptor gene CASR in 3q13q21..$^{15} 16$

Familial isolated hyperparathyroidism (FIHP; OMIM \#145000) is defined as hereditary PHPT without other associated neoplasias or endocrinopathies. ${ }^{17}$ The disease is dominantly inherited and characterised by benign uni- or multi-glandular parathyroid tumours. Germline mutations of the CASR gene have previously been reported in a subset of FIHP families. ${ }^{17}$ Based on linkage studies in a few large pedigrees, FIHP has also been suggested to represent genetic variants of $\mathrm{MENI}^{18}$ or HPT-JT syndrome. ${ }^{19}$ Following the

\section{Key points}

- Familial primary hyperparathyroidism (PHPT) is a heterogeneous disease, both with respect to the clinical presentation and the predisposing genetic defects involved. The main familial forms of PHPT are hyperparathyroidism-jaw tumour syndrome (HPT-JT), multiple endocrine neoplasia (MEN1), and familial isolated hyperparathyroidism (FIHP).

- The recently identified HRPT2 gene responsible for HPT-JT was screened for mutations in seven kindreds diagnosed with FIHP. Two of the families were found to segregate a constitutional HRPT2 mutation, including a splice mutation IVS2+1G $\rightarrow$ C in the first family and a missense mutation 191T $\rightarrow C$ (L64P) in the second family.

- We were able to document that L64P had occurred de novo in an affected woman who carried the mutation in a somatic and germline mosaic state. The other five FIHP kindreds were negative for germline mutations in all three genes identified for FIHP, HRPT2, MEN1, and CASR.

- In conclusion, we demonstrate that HRPT2 is a disease gene for $1 q$ linked FIHP and underline the possibility of mutations occurring de novo in this gene. The results further support that a subset of FIHP is a variant of HPTJT, which has implications for clinical diagnostic purposes and for improved understanding of parathyroid tumour development.

identification of the MENI gene, some families with FIHP have subsequently been shown to segregate constitutional MENI mutations, predominantly missense, suggesting that FIHP can be a variant or partial expression of MEN $1 .{ }^{20-24}$ The identification of HRPT2 provides a new and highly relevant candidate for the further elucidation of FIHP genetics. For this purpose, we investigated the possible involvement of HRPT2 in FIHP families. Our findings demonstrate the involvement of HRPT2 in a subset of such families.

Abbreviations: FIHP, familial isolated hyperparathyroidism; HPT-JT, hyperparathyroidism-jaw tumour syndrome; MEN, multiple endocrine neoplasia; PHPT, primary hyperparathyroidism 


\section{MATERIALS AND METHODS}

\section{Families}

Genetic analysis was performed on seven kindreds diagnosed with FIHP. The diagnosis of PHPT in the participating individuals was based on extensive and careful investigation in order to exclude the presence of MENI or FHH. Informed consent was obtained from all patients and the study was approved by the local ethics committees.

Family $\mathrm{l}$ is residing in France, and the members have been clinically followed since 1993 (fig 1, table 1). In this family all patients have been screened by a standardised established protocol by the French network on MEN disease (Groupe d'Etude des Tumeurs Endocrines-GTE/GENEM). ${ }^{25}$ In brief, this included biochemical measurements of serum and urinary calcium, PTH, phosphate, gastrin, insulin, peptide C, glucagon, chromogranin A, pancreatic polypeptide, basic prolactin, and growth hormone, as well as abdominal ultrasound and CT (of the kidneys, adrenal glands, liver, and pancreas), thoracic CT (to search for carcinoids), cervical ultrasound, and pituitary MRI. For the last 2 years, orthopentography has been performed for all members of the family.

The grandfather (I:2) was diagnosed at 59 years of age with PHPT following a period of symptoms suggestive of kidney stones. Two benign hyperplastic parathyroid glands were identified and surgically removed, since which time he has been clinically well. His two children from the second marriage (II:3 and II:5) have both been affected and treated surgically for PHPT. The daughter II:3 was diagnosed with kidney stones at the age of 32 years, and a single parathyroid adenoma, $1.8 \mathrm{~cm}$ in size with multiple cystic formations and haemorrhagic foci, was identified at surgery and removed. Nine years later, at 41 years of age, she had a recurrence of PHPT and a second parathyroid adenoma was removed. The patient is presently 53 years old, and has persistent hypercalcaemia at the upper limit with elevated PTH (103 ng/L). She has also developed osteous abnormalities typical for PHPT and recurrent hypercalciuria. Her brother (II:5) was diagnosed at 21 years of age with PHPT following an atypical clinical presentation with mental affective disturbance and kidney stones. A single adenoma was identified at surgery and removed. Eleven years later recurrent PHPT was noted and one additional enlarged parathyroid gland was removed, following which the patient has been asymptomatic. The grandson (III:4) was treated at 25 years of age for PHPT with removal of one large intrathymic parathyroid adenoma $(1.835 \mathrm{~g})$. The younger brother (III:6) is clinically and biochemically unaffected. The dizygotic twins (III:7 and III:8) are presently 9 years old and have serum calcium levels at the upper limit of normal but are otherwise without symptoms of PHPT. The presence of MEN1 syndrome in this family was excluded by clinical screening for related tumours and by negative MENI mutation analyses in all affected members. No tumours were detected or suspected using ortopenthography or renal CT scanning. The observation of two renal cysts in II:3, and one cyst in each of individuals II:3 and III: 4 were interpreted as normal findings because of their small size and benign appearance.

Family 2 (fig 2), which has previously been reported to exhibit FIHP linked to the HPT-JT locus, ${ }^{19}$ was clinically reexamined in this study. The family members included in the study were biochemically screened, with measurements of serum and urinary calcium, phosphate, albumin, and creatinine. The radiological screening included orthopentography and abdominal ultrasound. This revealed five individuals affected with PHPT related to cystic parathyroid adenomas, but without evidence of other endocrinopathies or neoplasias. The proband (IV:8) was diagnosed with PHPT at 22 years of age, and treated with parathyroidectomy to remove one adenoma. His grandmother (II:2) presented clinically with renal calculi in her forties. After recognition of PHPT at 58 years of age, two parathyroid adenomas were surgically removed, one of which was unusually large (4 g, $40 \mathrm{~mm}$ ). The proband's father (III:8) developed PHPT at 25 years of age, and a single adenoma was removed. Seventeen years later, at 42 years of age, he had recurrence of PHPT and a second parathyroid adenoma of $1.5 \mathrm{~g}$ was removed. He died in 2001 at the age of 51 years following a myocardial infarction. The father's three paternal aunts (II:3, II:4, and II:7) have not shown any clinical or biochemical symptoms of PHPT. Their respective children are similarly unaffected. The proband's aunts (III:2, III:3, and III:6) are clinically unaffected and have normal range total serum calcium levels. Two of his cousins (IV:1 and IV:3) were surgically treated for PHPT at 21 and 19 years of age respectively, with removal of one adenoma in each case.
Family 1 with HRPT2 mutation; IVS2 + IG $\rightarrow$ C

I

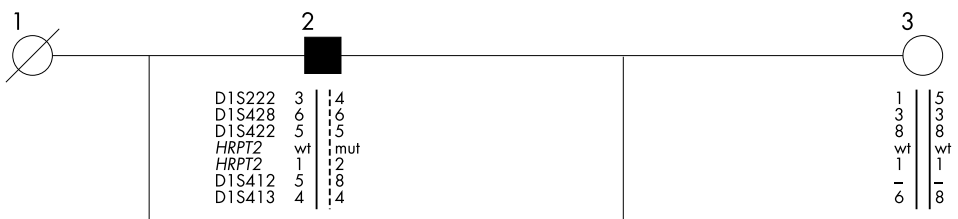

II
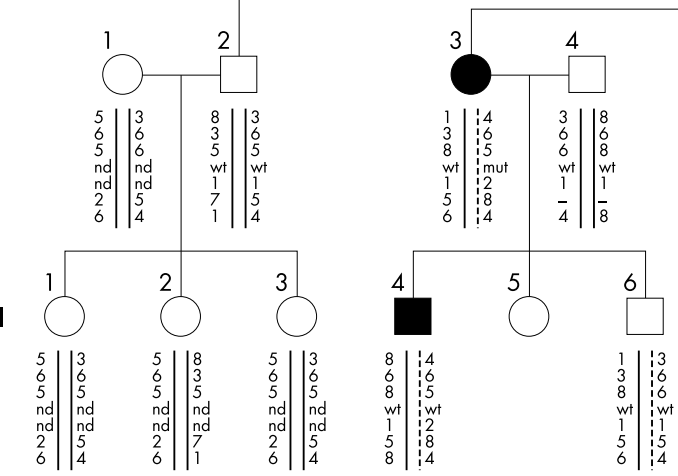

Figure 1 Pedigree of the previously unreported family 1 with autosomal dominant inheritance of isolated PHPT. Affected members operated for PHPT are shown as filled symbols and presently unaffected members as open symbols. The haplotypes defined by microsatellite markers flanking the HRPT2 gene are shown below each family member genotyped. Sequencing of the HRPT2 gene showed the wild type sequence (wt) or the presence of a splice mutation IVS2+1G $\rightarrow C$ (mut). The HRPT 2 allele 1 and 2 refers to the polymorphism (IVS2+28 C $\rightarrow$ T) detected in intron 2 by sequencing. The haplotype marked by a dotted line carries the mutation and is associated with the disease. 
Table 1 Clinical and genetic details of family 1 with FIHP in the study

\begin{tabular}{|c|c|c|c|c|c|c|c|}
\hline \multirow[b]{2}{*}{ Parameter } & \multicolumn{7}{|l|}{ Family member } \\
\hline & I:2 & II:3 & II:5 & III:4 & III:6 & III:7 & III:8 \\
\hline Sex & M & $\mathrm{F}$ & M & M & M & M & M \\
\hline Present age (years) & 79 & 53 & 45 & 27 & 19 & 9 & 9 \\
\hline Age at parathyroid first surgery & 59 & 32 & 21 & 25 & - & - & - \\
\hline Serum calcium (mmol/l) & 2.72 & 2.87 & 3.32 & 3.20 & 2.22 & 2.57 & 2.55 \\
\hline Serum PTH (pg/ml) & 70 & 74 & ND & 138 & 34 & 25.4 & 53.0 \\
\hline $\begin{array}{l}\text { No. of pathological glands } \\
\text { removed }\end{array}$ & 2 & 2 & 3 & 1 & - & - & - \\
\hline Histopathological diagnosis & Hyperplasia & Adenoma $\times 1$ & $\begin{array}{l}\text { Adenoma } \times 2 / \\
\text { hyperplasia }\end{array}$ & Adenoma & - & - & - \\
\hline $\begin{array}{l}\text { Disease associated haplotype } \\
\text { HRPT2 sequence }\end{array}$ & $\begin{array}{l}\text { Yes } \\
\text { IVS2+1G } \rightarrow C\end{array}$ & $\begin{array}{l}\text { Yes } \\
\text { IVS2+1G } \rightarrow C\end{array}$ & $\begin{array}{l}\text { Yes } \\
\text { IVS2+1G } \rightarrow \text { C }\end{array}$ & $\begin{array}{l}\text { Yes } \\
\text { IVS2+1G } \rightarrow \text { C }\end{array}$ & $\begin{array}{l}\text { No } \\
\text { wt }\end{array}$ & $\begin{array}{l}\text { Yes } \\
\text { IVS2+1G } \rightarrow \text { C }\end{array}$ & $\begin{array}{l}\text { Yes } \\
\text { IVS2+1G } \rightarrow \text { C }\end{array}$ \\
\hline
\end{tabular}

wt, Wild type sequence

Reference ranges: total serum calcium 2.20-2.60 mmol/l; intact serum PTH 10-60 ng/l.

Table 2 Clinical and genetic details for the seven FIHP kindreds in the study

\begin{tabular}{llllll}
\hline Family & Affected cases & Histopathology & HRPT2 & MEN1 & CASR \\
\hline 1 & 1 female/3 male & Adenoma/hyperplasia & IVS $+1 G \rightarrow C$ & Wild type & NA \\
2 & 2 female/3 male & Adenoma & $191 T \rightarrow C$ (L64P) & Wild type & NA \\
3 & 4 female & Adenoma & Wild type & Wild type & Wild type \\
4 & 2 female & Adenoma/hyperplasia & Wild type & Wild type & Wild type \\
5 & 3 female & Adenoma & Wild type & Wild type & Wild type \\
6 & 1 female/2 male & Hyperplasia & Wild type & Wild type & Wild type \\
7 & 3 female/1 male & Hyperplasia & Wild type & Wild type & Wild type \\
\hline \multirow{2}{*}{ NA, not analysed } & & & & \\
\end{tabular}

The other five cousins (IV:2 and IV:4-7) are presently unaffected, with serum calcium levels within the reference range. However, IV:5, who is presently 16 years old, has had four fractures. Neither of the proband's brothers (IV:9 or IV:10) has clinical or biochemical signs of PHPT. As previously reported, no case of jaw or renal tumour and no evidence of MEN1 has been found in this family ${ }^{19}$. Additional screening of III:6 with orthopentography and renal ultrasonography was negative.
FIHP families 3-7 (table 2) have been clinically described and screened for MENI mutations as previously reported. ${ }^{24}$ They were diagnosed as having PHPT on the basis of the clinical examinations, with findings of hypercalcaemia, increased parathyroid hormone (PTH), and family history of PHPT. The parathyroid lesions consisted of adenomas or hyperplasia. No other neoplastic lesions suggestive of MEN 1 or HPT-JT have been found, further supporting the diagnosis of FIHP. Furthermore, previous linkage analyses in these

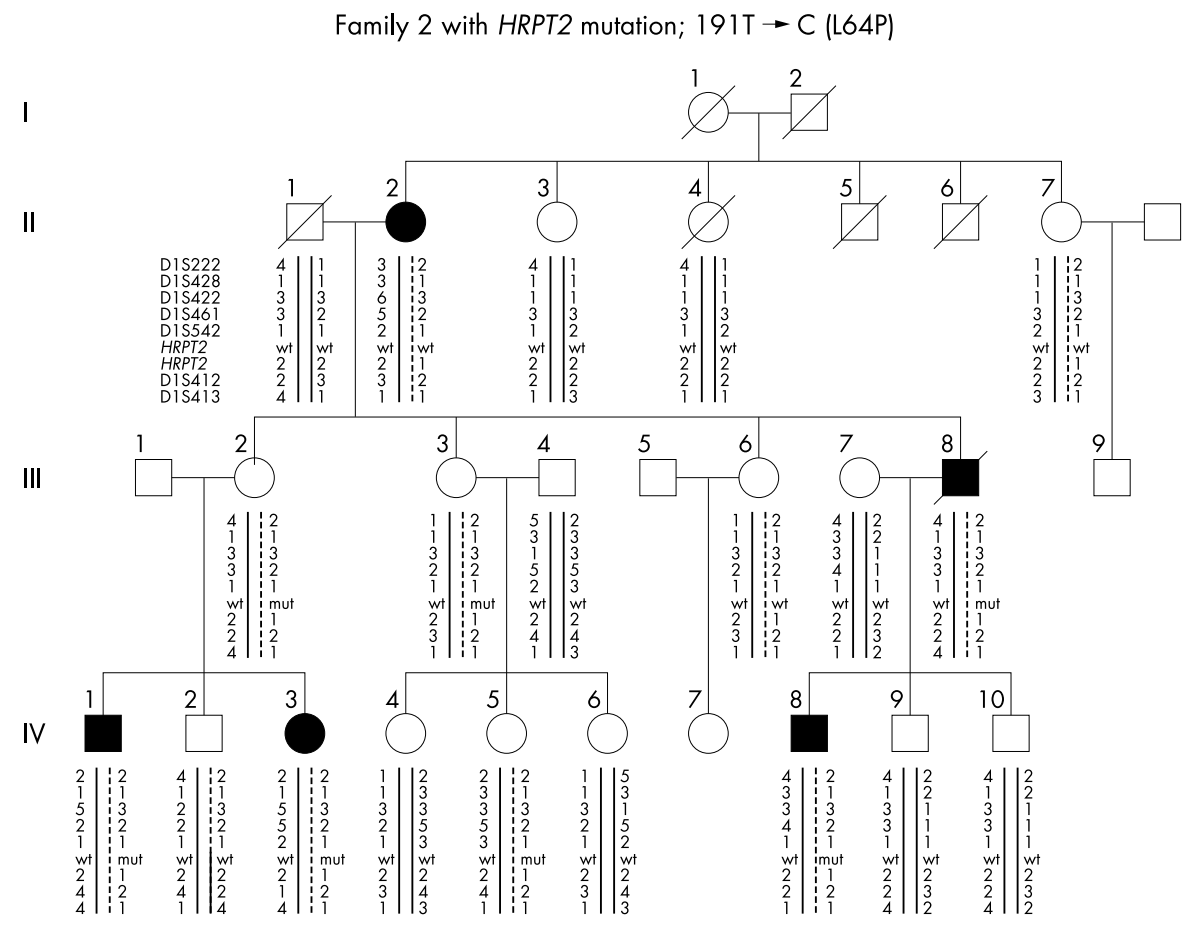

Figure 2 Pedigree and genotypes of the HRPT2 locus in family 2 , diagnosed with FIHP. Affected members operated for PHPT are shown as filled symbols and presently unaffected members as open symbols. The haplotypes defined by microstellite markers flanking the HRPT2 gene are shown below each family member genotyped. Sequencing of the HRPT2 gene showed the wild type sequence (wt) or the presence of a missense mutation L64P (mut) that occurred de novo in II:2. The HRPT2 allele 1 and 2 refers to the polymorphism (IVS7+33 (GA) 8 ) detected in intron 7 by sequencing. The haplotype marked by dotted line carries the polymorphism of HRPT2 and is associated with the disease. As the mutation occurred de novo in II: 2 , it is present on the affected haplotype in some branches of the family but not in others. 
Table 3 Primers and conditions used for mutation detection of HRPT2

\begin{tabular}{|c|c|c|c|c|c|c|c|c|}
\hline \multirow{3}{*}{$\begin{array}{l}\text { Exon } \\
1\end{array}$} & \multicolumn{4}{|c|}{ PCR-primers: $5^{\prime} \rightarrow 3^{\prime}$} & \multirow{3}{*}{$\begin{array}{l}\text { Product size } \\
\text { (bp) }\end{array}$} & \multirow{3}{*}{$\begin{array}{l}\left.\begin{array}{l}\text { Annealing } \\
\text { temp ( }\end{array}{ }^{\circ} \mathrm{C}\right) \\
58\end{array}$} & \multirow{2}{*}{\multicolumn{2}{|c|}{ Sequencing primers: $5^{\prime} \rightarrow 3^{\prime}$}} \\
\hline & \multicolumn{2}{|c|}{ Forward } & \multicolumn{2}{|c|}{ Reverse } & & & & \\
\hline & $1 F$ & $\begin{array}{l}\text { GAGGACGGCT } \\
\text { GTTAGTGCT }\end{array}$ & $1 \mathrm{R}$ & $\begin{array}{l}\text { ССССТTCTT } \\
\text { ССТАСССТTA }\end{array}$ & & & $1 F / 1 R / 1 S$ & $\begin{array}{l}\text { CGAAGGAGGA } \\
\text { GGAGGAAGAG }\end{array}$ \\
\hline 2 & $2 F$ & $\begin{array}{l}\text { TAAATGAAT } \\
\text { CCAGCCTGAAG }\end{array}$ & $2 \mathrm{R}$ & $\begin{array}{l}\text { AGGCCAGACC } \\
\text { CTGTCTCT }\end{array}$ & 251 & 62 & & $2 F / 2 R$ \\
\hline 3 & $3 F$ & $\begin{array}{l}\text { AAAGTGCTGG } \\
\text { GATTCTAGG }\end{array}$ & $3 R$ & $\begin{array}{l}\text { TGGACAAAAAT } \\
\text { GAAGGTAGG }\end{array}$ & 599 & 62 & $3 S$ & $\begin{array}{l}\text { GITGTGTATCAT } \\
\text { TGTATC }\end{array}$ \\
\hline $4-5$ & $4 \mathrm{~F}$ & $\begin{array}{l}\text { AACATGTIT } \\
\text { TGCAGAGCTG }\end{array}$ & $5 R$ & $\begin{array}{l}\text { CTCCTCAGGTTA } \\
\text { CTGCAATC }\end{array}$ & 451 & 62 & $4 F / 5 R / 4-5 S$ & $\begin{array}{l}\text { ACCTAGAGAA } \\
\text { AATCACCATA }\end{array}$ \\
\hline 6 & $6 \mathrm{~F}$ & $\begin{array}{l}\text { GGCCTAAAGAC } \\
\text { ACTGATACC }\end{array}$ & $6 R$ & $\begin{array}{l}\text { CGAACTIAAGA } \\
\text { GCAAAGAGG }\end{array}$ & 351 & 58 & & $6 \mathrm{~F} / 6 \mathrm{R}$ \\
\hline 7 & $7 F$ & $\begin{array}{l}\text { GAATGCCTG } \\
\text { CTGTGAAAA }\end{array}$ & $7 R$ & $\begin{array}{l}\text { TGTGAAGGAG } \\
\text { CTTGCATTT }\end{array}$ & 502 & 58 & & $7 F / 7 R$ \\
\hline 8 & $8 \mathrm{~F}$ & $\begin{array}{l}\text { CTCTGGATCAATA } \\
\text { TCTAGTAGTGG }\end{array}$ & $8 R$ & $\begin{array}{l}\text { GTCTTCAACGT } \\
\text { TACTACACTGC }\end{array}$ & 348 & 58 & & $8 F / 8 R$ \\
\hline 9 & $9 F$ & $\begin{array}{l}\text { ATGGTCATGC } \\
\text { TACTGCACTC }\end{array}$ & $9 R$ & $\begin{array}{l}\text { CCAACCCTTAC } \\
\text { CCTIAAACA }\end{array}$ & 251 & 58 & & $9 F / 9 R$ \\
\hline 10 & $10 F$ & $\begin{array}{l}\text { CAGAGATAGTCT } \\
\text { TAACCAGCTC }\end{array}$ & $10 R$ & $\begin{array}{l}\text { CTTCAACATGTG } \\
\text { CTACTCACAT }\end{array}$ & 384 & 58 & & $10 F / 10 R$ \\
\hline 11 & $11 \mathrm{~F}$ & $\begin{array}{l}\text { AACATGITCAG } \\
\text { TGGAGTAACC }\end{array}$ & $11 R$ & $\begin{array}{l}\text { TGCACTGTTAC } \\
\text { GATCTTTG }\end{array}$ & 251 & 60 & & $11 \mathrm{~F} / 11 \mathrm{R}$ \\
\hline $12-13$ & $12 \mathrm{~F}$ & $\begin{array}{l}\text { TGGTTAACTGA } \\
\text { AACTGCAGA }\end{array}$ & $13 R$ & $\begin{array}{l}\text { GTATCTCAATAT } \\
\text { CCTACGTACAGG }\end{array}$ & 713 & 60 & $\begin{array}{l}12 F / 12 S \\
13 R / 13 S\end{array}$ & $\begin{array}{l}\text { CAGTGTTGA } \\
\text { GAAGATAGTTG } \\
\text { CCCAAGCCA } \\
\text { CACTGATTATT }\end{array}$ \\
\hline 14 & $14 \mathrm{~F}$ & $\begin{array}{l}\text { ATCTTCCCA } \\
\text { TाTCATCACG }\end{array}$ & $14 \mathrm{R}$ & $\begin{array}{l}\text { CCCCATCTCT } \\
\text { TAAAAAGCAA }\end{array}$ & 321 & 58 & & $14 \mathrm{~F} / 14 \mathrm{R}$ \\
\hline 15 & $15 \mathrm{~F}$ & $\begin{array}{l}\text { TGCCTAAGGGA } \\
\text { TITATAGTAGC }\end{array}$ & $15 R$ & $\begin{array}{l}\text { ACATCATAT } \\
\text { GCGCAGAACT }\end{array}$ & 281 & 60 & & $15 F / 15 R$ \\
\hline 16 & $16 \mathrm{~F}$ & $\begin{array}{l}\text { GGCGTGTATAA } \\
\text { ACCCTGAAT }\end{array}$ & $16 R$ & $\begin{array}{l}\text { GAAAGAAGGG } \\
\text { AATAGGGAA }\end{array}$ & 401 & 60 & & $16 \mathrm{~F} / 16 \mathrm{R}$ \\
\hline 17 & $17 F$ & $\begin{array}{l}\text { GAGGAGTGTTAT } \\
\text { TTCTAGCTIATCC }\end{array}$ & $17 R$ & $\begin{array}{l}\text { GATCAATCTGTGA } \\
\text { CCTCTTCA }\end{array}$ & 301 & 60 & & $17 F / 17 R$ \\
\hline
\end{tabular}

Primers were constructed from alignment of the CDNA sequence (accession no. XM-029845) with the genomic sequence of AL390863 and AL139133. Primers $1 \mathrm{~F}$ and $17 \mathrm{R}$ are located within $5^{\prime}$ and $3^{\prime}$ UTR regions, while all other primers are from within intronic sequences.

families could not exclude the possible involvement of MENI and HRPT2 loci. ${ }^{24}$

\section{Mutation analyses of the HRPT2 and CASR genes}

Mutation screening of the HRPT2 gene was performed by sequencing the entire coding region in two or three affected family members representing each of the seven families. The primers used for amplification and sequencing as well as the annealing temperatures for the amplification are presented in table 3.
The 17 coding exons of HRPT2 were amplified as 15 different fragments with primers derived from the flanking intronic or $3^{\prime} / 5^{\prime}$ UTR regions, to allow detection of mutations in coding regions or affecting the splicing. The DNA (50 ng) was amplified in a mix of $1 \times$ Taq Gold buffer, $1.5 \mathrm{mmol} / \mathrm{l}$ $\mathrm{MgCl}_{2}, 1.25 \mathrm{mmol} / \mathrm{l}$ of each dNTP and $10 \mathrm{mmol} / \mathrm{l}$ oligonucleotide primer pair, $1.5 \mathrm{U}$ DNA polymerase (AmpliTaq Gold $^{\mathrm{TM}}$ ) in a final volume of $20 \mu \mathrm{l}$. The thermocycling conditions consisted of an initial denaturation of $95^{\circ} \mathrm{C}$, followed by 35 cycles of denaturation at $95^{\circ} \mathrm{C}$ for 40 seconds,
Germline FIHP mutations reported in this study

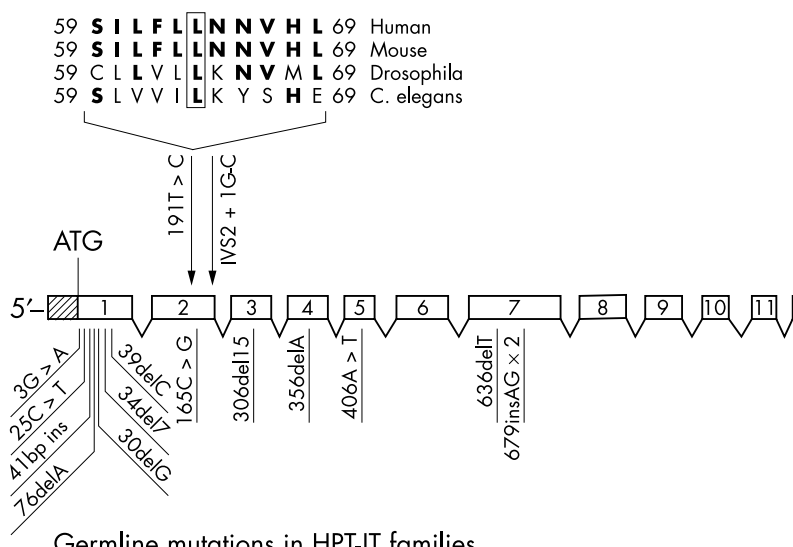

Figure 3 Schematic illustration of the HRPT2 gene and the germline mutations detected in it. The inactivating mutations reported in HPT-JT families ${ }^{326}$ are shown below the corresponding exons. Above is indicated the mutations found in FIHP families. The including missense mutation (L64P) has previously been reported by Carpten et al, and the nonsense alteration was identified in this study. The alignment of orthologous $3^{\prime}$ sequences of mouse, Drosophila, and Caenorhabtidis elegans are shown above the missense mutation 191T $\rightarrow C$ (L64P) to demonstrate that the amino acid is conserved among the different species. The positions of nucleotides are numbered from the initiating codon. 
annealing at $58-62^{\circ} \mathrm{C}$ for 30 seconds, and elongation at $72^{\circ} \mathrm{C}$ for 45 seconds, and a final extension at $72^{\circ} \mathrm{C}$ for 7 minutes.

Sequencing reactions were performed using the BigDye Terminator cycle sequencing kit (Perkin Elmer) with the following thermocycling conditions: denaturing at $98^{\circ} \mathrm{C}$ for 5 minutes, followed by 25 cycles of $96^{\circ} \mathrm{C}$ for 10 seconds, $50^{\circ} \mathrm{C}$ for 5 seconds, and $60^{\circ} \mathrm{C}$ for 4 minutes. The sequencing products were then purified with Sephadex G-50 (Amersham Pharmacia Biotech, Sweden) on MultiScreenHV Clear Plates (Millipore Corp, Bedford, MA, USA) and thereafter run in either a capillary sequencer ABI Prism 3700 DNA analyser or in an automated sequencer (ABI 377; PE Applied Biosystems, Foster City, CA, USA).

Sequencing of the mutated exon/intron was performed for all available members of families 1 and 2, as well as for the parathyroid adenoma from II:2 in family 2, using forward and reverse sequencing. The mutation in family $\mathrm{l}$ was confirmed by restriction cleavage assay. Each PCR product of exon 2 was cleaved with DdeI (Invitrogen) in a total volume of $100 \mu \mathrm{l}$, and separated on 3\% agarose gels. The presence of a mutation results in the introduction of a DdeI restriction site, leading to the addition of two shorter restriction fragments detected by gel electrophoresis. In addition, the mutation negative status of members II:1, II:7, and III:6 in family 2 was confirmed by sequencing of exon 2 using a different set of flanking primers. Sequencing of HRPT2 exon 2 and the flanking intronic region was performed on 215 normal unrelated control individuals, comprising 150 controls described by Carpten et $a^{3}$ and the 65 controls reported by Howell et al. ${ }^{26}$

In addition, sequencing of the six coding exons (2-7) of the CASR gene was carried out using the same primers and PCR conditions as described elsewhere ${ }^{27}$ in families 3-7 without identified HRPT2 mutations.

\section{Genotyping of microsatellite markers}

Genomic DNA was extracted from peripheral leukocytes using standard methods and genotyped with polymorphic microsatellite markers. Seven markers from the HRPT2 region in 1q25-q32 were selected, including cen-D1S222-D1S428D1S422-D1S461-D1S542-HRPT2-D1S412-D1S413-tel. The localisation and order of the markers are based on the information presented in Carpten et $\mathrm{al}^{3}$ and in the Genome Database (www.gdb.org). For all markers, the forward primer was labelled for fluorescent detection after electrophoresis on a laser fluorescent sequencing machine (ABI 377, PE Applied Biosystems). Polymerase chain reaction was performed as described for the mutation screening of HRPT2. The data were analysed using Genescan softwere (PE Applied Biosystems).

\section{RESULTS}

The seven kindreds studied here all had 2-5 members affected with PHPT related to benign parathyroid tumours (table 2). At the initial diagnosis there was no evidence of other endocrinopathies or tumours found in the families. During follow up, these patients have not presented with any signs suggestive of other familial syndromes such as MEN I or HPT-JT, thus further supporting the diagnosis of FIHP.

\section{HRPT2 mutations and mosaicism in FIHP}

The two HRPT2 germline mutations identified in the two families constitute of a missense mutation and a splice mutation (fig 3). Neither of these mutations was identified by sequencing of 215 normal reference individuals. Two polymorphisms (IVS2 $+28 \mathrm{C} \rightarrow \mathrm{T}$ and IVS7+33 $(\mathrm{GA})_{8}$ ) in intronic sequences were detected in two of the families and in normal reference individuals.
In family 1 , the base substitution $(\mathrm{G} \rightarrow \mathrm{C})$ detected at the boundary of exon 2 and intron 2 (IVS $2+\mathrm{lG} \rightarrow \mathrm{C}$; fig 3 ) is predicted to cause defective splicing. The mutation was found in all four affected family members (I:2, II:3, II:5, and III:4) and in both children (III:7 and III:8) of II:5, who are presently 9 years old and unaffected (fig 1). Furthermore, genotyping of markers from the HRPT2 region showed that all mutation carriers shared the same disease associated haplotype (fig 1 , table 1). Here, the intronic HRPT2 polymorphism $(\mathrm{T} / \mathrm{C})$ revealed at position +28 in intron 2 served as an intragenic marker of the affected haplotype.

In family 2, the missense mutation in exon 2 consisted of a base substitution (CTT $\rightarrow$ CCT) causing an amino acid change from leucine to proline at position 64 (L64P, fig 3). The mutation was present in four affected family members (III:8, IV:1, IV:3, and IV:8) and in three presently unaffected members (III:2, III:3, and IV:5) (fig 2). One of these mutation carriers is an obligate carrier (III:2) and one has a history of multiple fractures (IV:5). All mutation carriers were also shown to share the same disease associated haplotype of the HRPT2 region. The polymorphism detected in intron 7 $\left(\right.$ IVS7+33 $\left.(\mathrm{GA})_{8}\right)$ was also present on the affected haplotype, supporting the linkage results. The mutation was not detected either in the oldest affected family member (II:2) or in her three sisters (II:3, II:4, and II:7) and one daughter (III:6). However, two of these individuals (II:7 and III:6) carried the affected haplotype for the entire interval, including the intron 7 polymorphism (fig 2). Interestingly, the mutation (L64P) was also found in the parathyroid adenoma of II:2 but not in her leukocyte DNA. Repeated genotyping and mutation analyses on a new set of DNA samples from this family confirmed the findings in all cases. Taken together, the findings in family 2 suggest that the L64P mutation occurred de novo on the disease associated haplotype in individual II:2. This haplotype was then inherited with the mutation by three of her children (III:2, III:3, and III:8) but without the mutation by her daughter, III:6 (fig 2).

\section{FIHP families negative for HRPT2, CASR and MEN1}

In five families (3-7), no HRPT2 mutation were detected. Previously, these families had been screened for MENI mutations with negative results. ${ }^{24}$ In an attempt to investigate the third locus involved in FIHP, we addressed the CASR gene by screening for mutations in the six coding exons. However, no mutations could be demonstrated.

\section{DISCUSSION}

The seven families reported here were all shown to have FIHP, which in two of them was found with constitutional mutations of the HRPT2 gene. In family 1 , the HRPT2 mutation destroys the splice site at the $5^{\prime}$ end of intron 2. In family 2, the missense mutation (L64P) in exon 2 alters an evolutionarily conserved amino acid that is present among orthologous sequences such as mouse, Drosophila melanogaster, and Caenorhabditis elegans (fig 3). It can be speculated that the effect of the single residue alteration may change the local structure or interfere with the ability for parafibromin to interact with other proteins. In both families the inheritance of microsatellite alleles is in agreement with linkage of PHPT to the HRPT2 region, as also determined from analyses of intragenic polymorphisms. The mutations are present on the respective affected haplotypes, but were not detected in 215 normal controls. Taken together, these findings suggest the possible pathogenetic importance of the two mutations, thus demonstrating that HRPT2 is a disease gene for lq linked FIHP. In further support of the association between FIHP and $H R P T 2$, it can be noted that the parathyroid tumours from both families tended to be large and have cystic features, 
similar to that seen in HPT-JT. Furthermore, loss of heterozygosity of the wild type lq alleles in the parathyroid tumours of family members II:2, IV:1, and IV:8 in family 2 has previously been reported, ${ }^{19}$ in agreement with the likely tumour suppressor function of HRPT2. ${ }^{3}$

No mutations were identified in the remaining five FIHP families (3-7) in any of the three genes investigated (table 2). However, mutations in regulatory or intronic parts of HRPT2, $M E N 1$, and CASR cannot be excluded by this study. There is also a possibility that other chromosomal regions may contribute to the development of parathyroid tumours in FIHP.

In dissecting the genetic aetiology of FIHP, the diagnostic aspects are of great importance. Familial PHPT is recognised as a genetically heterogeneous disease that can occur either as a separate entity or as part of an inherited cancer syndrome such as MENl and HPT-JT. ${ }^{1}$ Therefore, some families with PHPT can initially present as isolated PHPT, but subsequently develop the full blown syndrome of HPT-JT or MEN ${ }^{28-30}$ while in others the diagnosis of FIHP remains during follow up. ${ }^{19-21}$ In the present study, the FIHP families with HRPT2 mutations have been followed up for more than 10 years, during which only benign PHPT has been diagnosed, and the possibility of MENI and HPT-JT has been carefully evaluated and excluded. Furthermore, affected members from three generations were investigated in both families, including several adult mutation carriers well above the expected age of onset for symptoms detectable at screening.

The missense and splice mutations detected in the study are not representative of the mutation spectra of families with HPT-JT syndrome (fig 3). In the initial publication of the HRPT2 cloning, 12 of the 13 different germline mutations were predicted to give impaired protein function due to truncation or premature stops. ${ }^{3}$ The only missense mutation detected was located at the first ATG, leading to loss of the initiation codon. ${ }^{3}$ All of these families were clinically characterised with PHPT, and in addition jaw tumours, renal lesions, or parathyroid carcinoma. ${ }^{31}$ Although based on a limited number of observations, it is striking that the HRPT2 mutation spectra in FIHP $v$ HPT-JT is similar to that observed for the MENI gene. With regard to the MENI gene, FIHP families predominantly have missense mutations, ${ }^{20-24}$ whereas in MENl families truncating or nonsense mutations are more frequent. ${ }^{13} 14$

In one of the FIHP families, the HRPT2 mutation (L64P) was not found in the initial mutation screening as it had occurred de novo. Extensive analysis of additional family members led to the identification of the mutation, which was reported in Carpten et $a^{3}$ and is further described in the present study. As illustrated in fig 2, three of the four children of II:2 inherited the affected haplotype with the disease mutation from their mother (II:2) and in turn passed the same mutated haplotype on to their respective children. However, the same affected haplotype was also inherited to her fourth daughter (III:6) without the mutation. This daughter has recently been thoroughly re-examined clinically and found to be clearly unaffected after examination of the parathyroids, the jaws, and the kidneys. In addition, the same affected haplotype was present without the mutation in one of the mother's sisters (II:7), who is also clinically unaffected. The mother has been surgically treated for PHPT, and genetically she carries the affected haplotype without the mutation in constitutional DNA isolated from her peripheral leukocytes. However, the mutation was present in the tumour DNA, which would suggest that the mother is somatic and germline mosaic for the initiating mutation. In this particular family, the mutation would then have occurred de novo during embryogenesis of II:2 on the chromosome with the affected haplotype. Owing to the mother's mosaicism, this haplotype was then passed three times with the mutation and once without it on to her four children. Similarly, mosaicism in II:2 would explain why the mutation is not present on the affected haplotype in leukocyte DNA although she is clinically affected with PHPT. Mosaicism has previously been observed in other hereditary diseases, for example retinoblastoma and neurofibromatosis, and has then been associated with similar discrepancies between the inheritance of marker alleles and disease mutation. ${ }^{32} 33$

In summary, we have demonstrated that constitutional mutations in the HRPT2 gene are likely to be associated with parathyroid tumourigenesis. Specifically, the involvement of HRPT2 is demonstrated to be a disease gene for lq linked FIHP. The finding that a subset of FIHP occurs as an allelic variant of HPT-JT has implications for clinical diagnostic purposes and for improved understanding of parathyroid tumour development. It is expected that further functional studies of mutations in the HRPT2 gene will provide relevant information to better explain the tissue specific involvements of HPT-JT and FIHP.

\section{ACKNOWLEDGEMENTS}

The work was supported by the Torsten and Ragnar Söderberg Foundations, the Swedish Cancer Foundation, the Wallenberg Foundation, the Milton Foundation, the Gustav V Jubilee Foundation, the Thuring Foundation, the Cornell Foundation, and the Stockholm County Council.

\section{Authors' affiliations \\ A Villablanca, L Forsberg, C Larsson, Department of Molecular Medicine, Karolinska Hospital, Stockholm, Sweden \\ A Villablanca, A Höög, Department of Oncology-Pathology, Karolinska Hospital, Stockholm, Sweden \\ A Calender, Laboratoire de Génétique et Cancer, UMR CNRS, Lyon, France \\ J-D Cheng, D Petillo, K Kahnoski, B T Teh, Van Andel Research Institute, Grand Rapids, Michigan, USA \\ C Bauters, Service d'Endocrinologie, CHRU de Lille, Lille, France \\ T Ebeling, P I Salmela, Department of Internal Medicine, Oulu University Hospital, Oulu, Finland \\ A-L Richardson, L Delbridge, B G Robinson, Cancer Genetics Unit, Kolling Institute of Medical Research, Royal North Shore Hospital and the Department of Molecular Medicine, University of Sydney, Sydney, Australia \\ A Meyrier, Service de Néphrologie, Hôpital Broussais, Paris, France C Proye, Service de Chirurgie Endocrine, CHRU de Lille, Lille, France J D Carpten, Cancer Genetics Branch, National Human Genome Research Institute, NIH, Bethesda, MD, USA}

Correspondence to: A Villablanca, Departments of Molecular Medicine and Oncology-Pathology, Karolinska Hospital, Stockholm, Sweden; andrea.villablanca@cmm.ki.se

Received 3 October 2003

Accepted 6 October 2003

\section{REFERENCES}

1 Villablanca A, Höög A, Larsson C, Teh BT. Molecular genetics of familial hyperparathyroidism. J Endo Genet 2001;2:3-12.

2 Marx SJ, Simonds WF, Agarwal SK, Burns AL, Weinstein LS, Cochran C, Skarulis MC, Spiegel AM, Libutti SK, Alexander HR Jr, Chen CC, Chang R, Chandrasekharappa SC, Collins FS. Hyperparathyroidism in hereditary syndromes: special expressions and special managements. J Bone Miner Res 2002;17:N37-43.

3 Carpten JD, Robbins CM, Villablanca A, Forsberg L, Presciuttini S, BaileyWilson J, Simonds WF, Gillanders EM, Kennedy AM, Chen JD, Agarwal SK Sood R, Jones MP, Moses TY, Haven C, Petillo D, Leotlela PD, Harding B, Cameron D, Pannett AA, Hoog A, Heath H, James-Newton LA, Robinson B, Zarbo RJ, Cavaco BM, Wassif W, Perrier ND, Rosen IB, Kristoffersson U, Turnpenny PD, Farnebo LO, Besser GM, Jackson CE, Morreau H, Trent JM, Thakker RV, Marx SJ, Teh BT, Larsson C, Hobbs MR. HRPT2, encoding parafibromin, is mutated in hyperparathyroidism-jaw tumor syndrome. Nat Genet 2002;32:676-80. 
4 Jackson CE, Norum RA, Boyd SB, Talpos GB, Wilson SD, Taggart RT, Mallette LE. Hereditary hyperparathyroidism and multiple ossifying jaw fibromas: a clinically and genetically distinct syndrome. Surgery 1990;108:1006-12, discussion 1012-13.

5 Szabo J, Heath B, Hill VM, Jackson CE, Zarbo RJ, Mallette LE, Chew SL, Besser GM, Thakker RV, Huff V, Leppert ML, Heath HR. Hereditary hyperparathyroidism-jaw tumor syndrome: the endocrine tumor gene HRPT2 maps to chromosome 1q21-q31. Am J Hum Genet 1995;56:944-50

6 Teh BT, Farnebo F, Kristoffersson U, Sundelin B, Cardinal J, Axelson R, Yap A, Epstein M, Heath H 3rd, Cameron D, Larsson C. Autosomal dominant primary hyperparathyroidism and jaw tumor syndrome associated with renal hamartomas and cystic kidney disease: linkage to 1q21-q32 and loss of the wild type allele in renal hamartomas. J Clin Endocrinol Metab 1996:81:4204-11.

7 Haven CJ, Wong FK, van Dam EW, van der Juijt R, van Asperen C, Jansen J, Rosenberg C, de Wit M, Roijers J, Hoppener J, Lips CJ, Larsson C, Teh BT, Morreau H. A genotypic and histopathological study of a large Dutch kindred with hyperparathyroidism-jaw tumor syndrome. J Clin Endocrinol Metab 2000;85: 1449-54.

8 Larsson C, Skogseid B, Oberg K, Nakamura Y, Nordenskjold M. Multiple endocrine neoplasia type 1 gene maps to chromosome 11 and is lost in insulinoma. Nature 1988;332:85-7.

9 Chandrasekharappa SC, Guru SC, Manickam P, Olufemi SE, Collins FS, Emmert-Buck MR, Debelenko LV, Zhuang Z, Lubensky IA, Liotta LA, Crabtree JS, Wang Y, Roe BA, Weisemann J, Boguski MS, Agarwal SK, Kester MB, Kim YS, Heppner C, Dong Q, Spiegel AM, Burns AL, Marx SJ. Positional cloning of the gene for multiple endocrine neoplasia-type 1. Science 1997:276:404-7.

10 Lemmens I, Van de Ven WJ, Kas K, Zhang CX, Giraud S, Wautot V Buisson N, De Witte K, Salandre J, Lenoir G, Pugeat M, Calender A, Parente F, Quincey D, Gaudray P, De Wit MJ, Lips CJ, Hoppener JW, Khodaei S, Grant AL, Weber G, Kytola S, Teh BT, Farnebo F, Thakker RV, et al. Identification of the multiple endocrine neoplasia type 1 (MEN1) gene. The European Consortium on MEN1. Hum Mol Genet 1997;6:1 177-83.

11 Agarwal SK, Guru SC, Heppner C, Erdos MR, Collins RM, Park SY, Saggar S Chandrasekharappa SC, Collins FS, Spiegel AM, Marx SJ, Burns AL. Menin interacts with the AP1 transcription factor JunD and represses JunD-activated transcription. Cell 1999;96:143-52.

12 Poisson A, Zablewska B, Gaudray P. Menin interacting proteins as clues toward the understanding of multiple endocrine neoplasia type 1. Cancer Lett 2003;189:1-10.

13 Agarwal SK, Kester MB, Debelenko LV, Heppner C, Emmert-Buck MR, Skarulis MC, Doppman JL, Kim YS, Lubensky IA, Zhuang Z, Green JS, Guru SC, Manickam P, Olufemi SE, Liotta LA, Chandrasekharappa SC, Collins FS, Spiegel AM, Burns AL, Marx SJ. Germline mutations of the MEN1 gene in familial multiple endocrine neoplasia type 1 and related states. Hum Mol Genet 1997:6:1169-75.

14 Bassett JH, Forbes SA, Pannett AA, Lloyd SE, Christie PT, Wooding C, Harding B, Besser GM, Edwards CR, Monson JP, Sampson J, Wass JA Wheeler MH, Thakker RV. Characterization of mutations in patients with multiple endocrine neoplasia type 1. Am J Hum Genet 1998:62:232-44.

15 Pollak MR, Brown EM, Estep HL, McLaine PN, Kifor O, Park J, Hebert SC, Seidman CE, Seidman JG. Autosomal dominant hypocalcaemia caused by a $\left.\mathrm{Ca}^{2+}\right)$-sensing receptor gene mutation. Nat Genet 1994;8:303-7.

16 Carling $T$, Szabo E, Bai M, Ridefelt $P$, Westin G, Gustavsson P, Trivedi S, Hellman P, Brown EM, Dahl N, Rastad J. Familial hypercalcemia and hypercalciuria caused by a novel mutation in the cytoplasmic tail of the calcium receptor. J Clin Endocrinol Metab 2000;85:2042-7.

17 Simonds WF, James-Newton LA, Agarwal SK, Yang B, Skarulis MC, Hendy GN, Marx SJ. Familial isolated hyperparathyroidism: clinical and genetic characteristics of 36 kindreds. Medicine (Baltimore) 2002;81:1-26.
18 Kassem M, Zhang X, Brask S, Eriksen EF, Mosekilde L, Kruse TA. Familial isolated primary hyperparathyroidism. Clin Endocrinol (Oxf) 1994;41:415-20

19 Teh BT, Farnebo F, Twigg S, Hoog A, Kytola S, Korpi-Hyovalti E, Wong FK, Nordenstrom J, Grimelius L, Sandelin K, Robinson B, Farnebo LO, Larsson C. Familial isolated hyperparathyroidism maps to the hyperparathyroidism-jaw tumor locus in 1q21-q32 in a subset of families. J Clin Endocrinol Metab 1998;83:21 14-20

20 Teh BT, Esapa CT, Houlston R, Grandell U, Farnebo F, Nordenskjold M, Pearce CJ, Carmichael D, Larsson C, Harris PE. A family with isolated hyperparathyroidism segregating a missense MEN1 mutation and showing loss of the wild-type alleles in the parathyroid tumors. Am J Hum Genet 1998;63:1544-9.

21 Kassem M, Kruse TA, Wong FK, Larsson C, Teh BT. Familial isolated hyperparathyroidism as a variant of multiple endocrine neoplasia type 1 in a large Danish pedigree. J Clin Endocrinol Metab 2000;85:165-7.

22 Honda M, Tsukada T, Tanaka H, Maruyama K, Yamaguchi K, Obara T, Yamaji T, Ishibashi M. A novel mutation of the MEN1 gene in a Japanese kindred with familial isolated primary hyperparathyroidism. Eur J Endocrinol 2000; 142:138-43.

23 Cetani F, Pardi E, Giovannetti A, Vignali E, Borsari S, Golia F, Cianferotti L, Viacava P, Miccoli P, Gasperi M, Pinchera A, Marcocci C. Genetic analysis of the MEN1 gene and HPRT2 locus in two Italian kindreds with familial isolated hyperparathyroidism. Clin Endocrinol (Oxf) 2002;56:457-64.

24 Villablanca A, Wassif WS, Smith T, Hoog A, Vierimaa O, Kassem M, Dwight T, Forsberg L, Du Q, Learoyd D, Jones K, Stranks S, Juhlin C, Teh BT, Carling T, Robinson B, Larsson C. Involvement of the MEN1 gene locus in familial isolated hyperparathyroidism. Eur J Endocrinol 2002;147:313-22.

25 Chanson P, Cadiot G, Murat A. Management of patients and subjects at risk for multiple endocrine neoplasia type 1: MEN 1. GENEM 1: Groupe d'Etude des Neoplasies Endocriniennes Multiples de Type 1. Horm Res 1997:47:211-20.

26 Howell VM, Haven CJ, Kahnoski K, Khoo SK, Petillo D, Chen J, Fleuren GJ, Robinson BG, Delbridge LW, Philips J, Nelson AE, Krause U, Hammje K, Dralle H, Hoang-Vu C, Gimm O, Marsh DJ, Morreau H, Teh BT. HRPT2 mutations are associated with malignancy in sporadic parathyroid tumours. J Med Genet 2003:40:657-63.

27 Chikatsu N, Fukumoto S, Suzawa M, Tanaka Y, Takeuchi Y, Takeda S, Tamura Y, Matsumoto T, Fujita T. An adult patient with severe hypercalcaemia and hypocalciuria due to a novel homozygous inactivating mutation of calcium-sensing receptor. Clin Endocrinol (Oxf) 1999:50:537-43.

28 Perrier ND, Villablanca A, Larsson C, Wong M, Ituarte P, Teh BT, Clark OH. Genetic screening for MEN1 mutations in families presenting with familial primary hyperparathyroidism. World J Surg 2002;26:907-13.

29 Wassif WS, Farnebo F, Teh BT, Moniz CF, Li FY, Harrison JD, Peters TJ, Larsson C, Harris P. Genetic studies of a family with hereditary hyperparathyroidism-jaw tumour syndrome. Clin Endocrinol (Oxf) 1999;50:191-6.

30 Miedlich S, Lohmann T, Schneyer U, Lamesch P, Paschke R. Familial isolated primary hyperparathyroidism-a multiple endocrine neoplasia type 1 variant? Eur J Endocrinol 2001;145:155-60.

31 Williamson C, Cavaco BM, Jauch A, Dixon PH, Forbes S, Harding B, Holtgreve-Grez H, Schoell B, Pereira MC, Font AP, Loureiro MM, Sobrinho LG, Santos MA, Thakker RV, Jausch A. Mapping the gene causing hereditary primary hyperparathyroidism in a Portuguese kindred to chromosome 1q22q31. J Bone Miner Res 1999:14:230-9.

32 Sippel KC, Fraioli RE, Smith GD, Schalkoff ME, Sutherland J, Gallie BL, Dryja TP. Frequency of somatic and germ-line mosaicism in retinoblastoma: implications for genetic counseling. Am J Hum Genet 1998;62:610-19.

33 Youssoufian H, Pyeritz RE. Mechanisms and consequences of somatic mosaicism in humans. Nat Rev Genet 2002;3:748-58. 